\title{
Tilapia (Oreochromis niloticus) as a Biondicator of Copper and Cadmium Toxicity. A Bioavailability Approach
}

\author{
Maria A. Silva, ${ }^{a}$ Tatiana C. S. Motta, ${ }^{a}$ Diogo B. Tintor, ${ }^{b}$ Thiago A. Dourado, ${ }^{b}$ \\ Amanda L. Alcântara, ${ }^{b}$ Amauri A. Menegário ${ }^{b}$ and José R. Ferreira ${ }^{*, a, c}$ \\ ${ }^{a}$ Centro de Energia Nuclear na Agricultura, Universidade de São Paulo (USP), \\ Av. Centenário, 303, 13400-970 Piracicaba-SP, Brazil \\ ${ }^{b}$ Centro de Estudos Ambientais, Universidade Estadual Paulista (UNESP), \\ Av. 24A, 1515, 13506-900 Rio Claro-SP, Brazil \\ 'Polo Regional Centro Sul, Agência Paulista de Tecnologia do Agronegócio (APTA), \\ Rod. São Paulo 127, Km 30, 13400-970 Piracicaba-SP, Brazil
}

\begin{abstract}
The acute toxicity of copper and cadmium in Oreochromis niloticus was evaluated through a $96 \mathrm{~h}$ static assay. Precipitation of $\mathrm{Cu}$ and co-precipitation of $\mathrm{Cd}$ in the presence of $\mathrm{Cu}$ were noted, being indicative of differences in nominal and actual concentrations of metals. Under these conditions, $\mathrm{LC}_{50-96 \mathrm{~h}}$ was determined as $3.53 \mathrm{mg} \mathrm{L}^{-1} \mathrm{Cu}, 20.1 \mathrm{mg} \mathrm{L}^{-1} \mathrm{Cd}$ and $1.36 \mathrm{mg} \mathrm{L}^{-1}(\mathrm{Cu}+\mathrm{Cd})$. Besides the quantitative determinations of total dissolved metals in water, considerations on $\mathrm{Cd} / \mathrm{Cu}$ interactions in aquatic media were presented, allowing the assessment for metals speciation. Data revealed that alkalinity, hardness, dissolved organic carbon and formation of inorganic complexes reduce metal availabilities, mainly in relation to $\mathrm{Cu}$. In spite of this, the $\mathrm{LC}_{50}$ for $\mathrm{Cd}$ was significantly reduced in the presence of $\mathrm{Cu}$, matching environmental realistic values. Based on simulated fate of metals, hardness may impair a reduction of 18 and $2 \%$ in metal activities, respectively to $\mathrm{Cu}$ and $\mathrm{Cd}$.
\end{abstract}

Keywords: Oreochromis niloticus, metals acute toxicity, bioindicator, chemical speciation, bioavailability

\section{Introduction}

Cadmium and copper have been intensively investigated through fish bioassays in acute and chronic exposures. ${ }^{1-11}$

The contamination of aquatic ecosystems by these metals is a consequence of the rapid population growth, increased urbanization, expanded agricultural activities and exploitation of natural resources, threatening the biota in these ecosystems. ${ }^{9,12,13}$

Cadmium, a non-essential metal, has been investigated in environmental studies due to its toxicity to marine species, even when present in low concentrations. Exposure to this chemical element may disturb the central functions and physiological processes, thus leading to diseases in organisms. ${ }^{4,14,15}$ Cadmium exposure may lead to adverse effects on fish growth, reproduction, liver (and other organs) functions and inhibition of calcium uptake by

*e-mail: ferreira@cena.usp.br the gills, causing hypocalcemia, which represents the key mechanism of toxicity induced by this metal. ${ }^{4,16}$

Copper is an essential element which plays an important role in cellular metabolism of organisms. When present in higher concentrations, however, it may become toxic. ${ }^{13}$ The effects of copper toxicity in fish include histopathological alterations in the liver and gills, growth reduction, oxidative stress damage to hepatic metabolism and inhibition of enzymes activity $\mathrm{Na}^{+} / \mathrm{K}^{+}$-ATPase, resulting in $\mathrm{Na}^{+}$homeostasis break down. ${ }^{17,18}$ In this context, several experiments have been carried out with tilapia, generally involving the species Oreochromis niloticus and Oreochromis mossambicus used as indicator organisms in field surveys. ${ }^{7}, 19$

In view of its easy handling, adaptation to confinement, laboratory maintenance, susceptibility to various pollutants and economic importance, the species $O$. niloticus has been widely used in environmental studies as well as in evaluating the toxicity of contaminants in aquatic ecosystems. ${ }^{20-22}$ 
In the present work, the average lethal concentrations estimated $\left(\mathrm{LC}_{50-96 \mathrm{~h}}\right)$ for $\mathrm{CuCl}_{2}, \mathrm{CdCl}_{2}$ and their combinations in $O$. niloticus were determined. Emphasis was given to the acute poisoning signs in fish under stress conditions to these chemicals during experimental exposures. To the best knowledge of the authors, the combined toxicity of mixed solutions of $\mathrm{CuCl}_{2}+\mathrm{CdCl}_{2}$ to this species was demonstrated for the first time.

As fish under stress conditions produce metallothioneins (Mts) as a response for essential and non-essential metals uptake, another objective of this work was to predict concentrations of the investigated metals in order to assess for the dynamic of Mts formation in O. niloticus at sub-lethal levels inducing its formation in a given concentration interval. In addition, several aspects related to the fish bioassay structure and operation were found out. Finally, under the established conditions, the availability of both metals to fish were simulated by using an aquatic speciation model.

\section{Experimental}

All research protocols in this work followed guidelines of the Environmental Protection Agency ${ }^{23}$ and Associação Brasileira de Normas Técnicas (ABNT: NBR 15088) ${ }^{24}$ for acute toxicity test with fish, handling animals gently and carefully to minimize stress. Regarding disposal, all organisms, including control, were humanely destroyed according to an appropriate manner. All effluents were properly purified before discharge.

Juvenile specimens of $O$. niloticus with an average weight of $10 \mathrm{~g}$ were collected at fish farms and transported to the laboratory in plastic bags containing up to 100 individuals. Prior to the experiments, fish were acclimated in $500 \mathrm{~L}$ water tanks during a 20 day period and offered $32 \%$ protein extruded feed. The water from these tanks was purified through a system of Dry-type Wet filtration, and flow rate was $3.0 \mathrm{~L} \mathrm{~h}^{-1}$.

The water used for acclimation and experimentation came from a local potable network supply, following a minimum $48 \mathrm{~h}$ residence time to allow spontaneous dechlorination.

During the acclimation period, physico-chemical variables were daily checked and mortalities were taking into account. The water temperature was maintained as $26 \pm 1{ }^{\circ} \mathrm{C}$, by using an electronic $300 \mathrm{~W}$ heater, and a photoperiod of $12 \mathrm{~h}$ light and $12 \mathrm{~h}$ dark was set. These procedures were maintained for the whole experimental period, according to ABNT: NBR 15088. ${ }^{24}$

Experiments with copper chloride, cadmium chloride or combinations of both were carried out during a $96 \mathrm{~h}$ period, for determining the acute toxicity of the metals to $O$. niloticus. Assays were performed in static exposure system.

Concentrations for acute toxicity assays were selected in preliminary tests, during $48 \mathrm{~h}$. Values were established in the range of the highest nominal concentration of toxic agent in which no lethality was observed (NOEC) and the lowest nominal concentration of toxic agent which caused $100 \%$ lethality of organisms (LOEC). ${ }^{23}$

Metal concentrations related to static acute toxicity tests for copper chloride and copper plus cadmium chlorides were: $0,0.5,1.0,2.5,5.0$ and $10.0 \mathrm{mg} \mathrm{L}^{-1}$ and for cadmium chloride $0,1.0,5.0,10.0,25.0$ and $50.0 \mathrm{mg} \mathrm{L}^{-1}$. All tests were performed in triplicate, involving the placement of 10 fish inside a $60 \mathrm{~L}$ resistant plastic aquarium filled with $40 \mathrm{~L}$ solution. In the experimental tanks, fish were subjected to a second $48 \mathrm{~h}$ period of acclimation. Fish were not fed $24 \mathrm{~h}$ prior to the start of acute toxicity tests. ${ }^{23,24}$

Temperature, $\mathrm{pH}$, dissolved oxygen, ammonium, total dissolved copper and cadmium were monitored at the beginning of the tests and at every $24 \mathrm{~h}$, whereas total hardness was checked only at the beginning and at the end of the assays in the controls.

A mobile multiple analyzer YSI Incorporated 556 MPS (Ohio, USA) was used for temperature, $\mathrm{pH}$ and dissolved oxygen quantification. Total metals were determined with a series 6000 inductively coupled plasma optical emission spectrometer (ICP OES) from Thermo Scientific (Waltham, USA). Total hardness was determined by ethylenediaminetetraacetic acid (EDTA) titration, ${ }^{25}$ and ammonia $\left(\mathrm{NH}_{3}-\mathrm{N}\right)$ obtained by calculation, taking into account the ammonium ion quantification $\left(\mathrm{NH}_{4}-\mathrm{N}\right)$ determined by flow injection conductometry, ${ }^{26}$ as well as $\mathrm{pH}$ and temperature of the water samples. ${ }^{23}$ The $\mathrm{NH}_{3}$ contents were estimated based on the reversible reactions between $\mathrm{NH}_{4}$ and $\mathrm{NH}_{3}$ assessed by the $\mathrm{pH}$ values and aquarium temperatures during water sample collections. Previously to chemical analysis, the water samples were filtered through a $0.45 \mu \mathrm{m}$ filter. Concentrations of metals were quantified in terms of its most toxic fraction to fish, i.e., soluble metals. Alkalinity was estimated by the WHAM 7.0 model. ${ }^{27}$ Through the mathematical model, metals speciation were calculated as well. To this end, three concentrations of metals, in isolated and in combined conditions, with the minimum and maximum values of hardness were selected. Ammonium ion and temperature were measured at the aquariums.

Feces and other waste were daily removed through siphoning. Dead fishes were removed from aquariums every $24 \mathrm{~h}$. At the $96 \mathrm{~h}$, the surviving fish were killed by hypothermia, by transferring them from the aquariums to an ice water bath. 
Statistical analysis to assess for the dosage against effect on the biota for the specific metal and its combination involved analysis of variance with the SAS System. For differences among treatments the statistical method Trimmed Spearman-Karber ${ }^{28}$ was used, determining the $\mathrm{LC}_{50-96 \mathrm{~h}}$, all calculations were performed by the statistical computer program $\mathrm{LC}_{50}$ Programs JSPear Test, Montreal, Canada.

\section{Results and Discussion}

The water quality data (Table 1) were similar among treatments, thus reducing the possibility of mortality due to the water quality alterations; these values were within the recommended ranges. ${ }^{23}$

Levels of ammonia were included in the above statement and in all situations, according to the temperature and $\mathrm{pH}$ of the bioassay conditions, the ammonia concentrations were much lower than those that caused mortalities for larvae and fingerlings of $O$. niloticus. ${ }^{29}$

Figures 1, 2 and 3 show the percentage mortalities obtained in each of the acute tests with $\mathrm{CuCl}_{2}, \mathrm{CdCl}_{2} \cdot \mathrm{H}_{2} \mathrm{O}$ and $\mathrm{CuCl}_{2}+\mathrm{CdCl}_{2} \cdot \mathrm{H}_{2} \mathrm{O}$ during the exposure period of $96 \mathrm{~h}$, respectively.

Statistical variance analysis indicates that mortality is explained by metal concentration, as the determination coefficients were high, $R^{2}(\mathrm{Cu})=0.9551, \mathrm{R}^{2}(\mathrm{Cd})=0.9522$ and $\mathrm{R}^{2}(\mathrm{Cu}+\mathrm{Cd})=0.8885$. The low $\mathrm{R}^{2}(\mathrm{Cu}+\mathrm{Cd})$ can be due to the chemical interactions between the two metals in combination, as discussed below, indicating how complex this link can be.

According to Klemm et al., ${ }^{30}$ the mortality rates for the control treatments in the three assays were within acceptable limits, as control mortalities did not exceed $20 \%$

Table 1. Range of variation for $\mathrm{pH}$, temperature, D.O, total hardness and ammonia determined in the experimental aquariums used to establish the acute toxicity $96 \mathrm{~h}$ test with $O$. niloticus

\begin{tabular}{lccccc}
\hline & & Control & $\mathrm{CuCl}_{2}$ & $\mathrm{CdCl}_{2} \cdot \mathrm{H}_{2} \mathrm{O}$ & $\mathrm{CuCl}_{2}+\mathrm{CdCl}_{2} \cdot \mathrm{H}_{2} \mathrm{O}$ \\
\hline Temperature $/{ }^{\circ} \mathrm{C}$ & Min & $24.45 \pm 0.85$ & $25.23 \pm 0.05$ & $23.57 \pm 0.01$ & $24.28 \pm 0.04$ \\
& Max & $25.44 \pm 0.30$ & $25.87 \pm 0.02$ & $25.50 \pm 0.07$ & $25.64 \pm 0.07$ \\
$\mathrm{pH}$ & Min & $6.91 \pm 0.29$ & $6.74 \pm 0.55$ & $6.64 \pm 0.03$ & $6.80 \pm 0.00$ \\
& Max & $7.42 \pm 0.12$ & $7.74 \pm 0.07$ & $7.20 \pm 0.09$ & $7.60 \pm 0.00$ \\
D.O / (mg L-1) & Min & $7.38 \pm 0.39$ & $7.58 \pm 0.11$ & $6.77 \pm 0.17$ & $7.06 \pm 0.92$ \\
& Max & $8.19 \pm 0.22$ & $8.83 \pm 0.29$ & $8.28 \pm 0.45$ & $8.56 \pm 0.20$ \\
Ammonia / $\left(\mathrm{mg} \mathrm{L}^{-1}\right)$ & Min & $0.02 \pm 0.01$ & $0.01 \pm 0.00$ & $0.01 \pm 0.00$ & $0.01 \pm 0.00$ \\
& Max & $0.08 \pm 0.03$ & $0.10 \pm 0.02$ & $0.04 \pm 0.01$ & $0.13 \pm 0.03$ \\
Total hardness / $\left(\mathrm{mg} \mathrm{L}^{-1} \mathrm{CaCO}_{3}\right)$ & Min & $68.54 \pm 0.25$ & - & - & - \\
& Max & $84.30 \pm 0.14$ & - & - & - \\
\hline
\end{tabular}

Min: minimum values of the parameters; Max: maximum values of the parameters; D.O: dissolved oxygen.

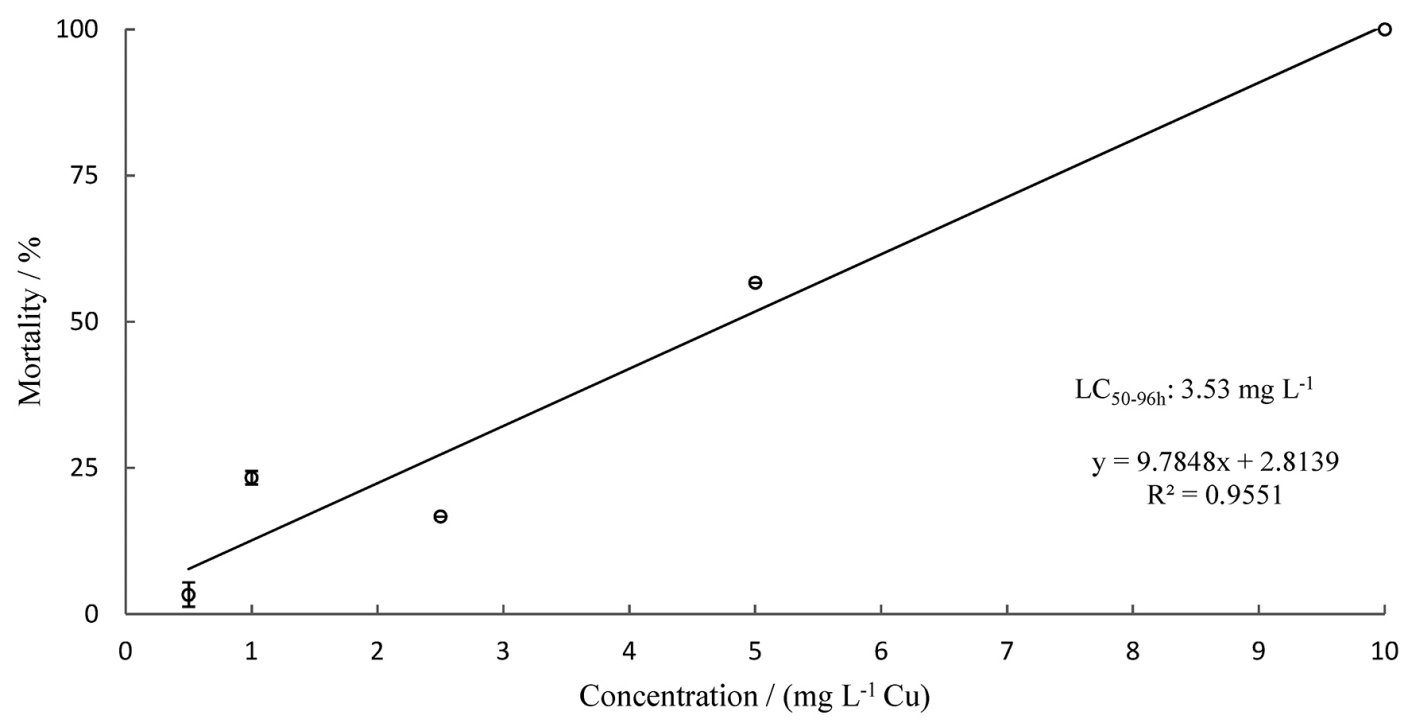

Figure 1. Mortality (\%) of Oreochromis niloticus, as a function of metal concentration in the $96 \mathrm{~h}$ acute toxicity test with $\mathrm{CuCl}_{2}$. 


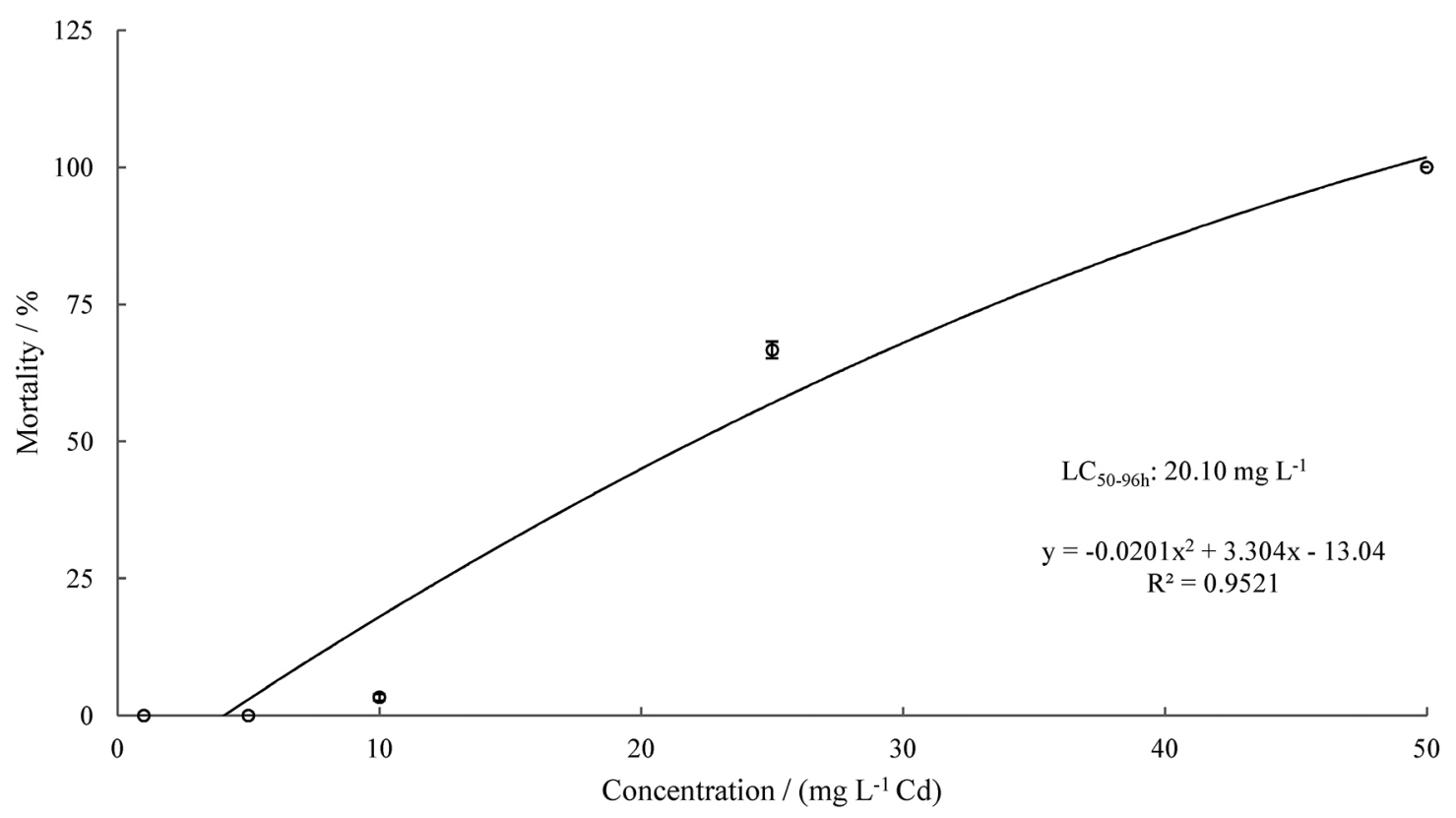

Figure 2. Mortality (\%) of Oreochromis niloticus, as a function of metal concentration in the $96 \mathrm{~h}$ acute toxicity test with $\mathrm{CdCl}_{2} \cdot \mathrm{H}_{2} \mathrm{O}$.

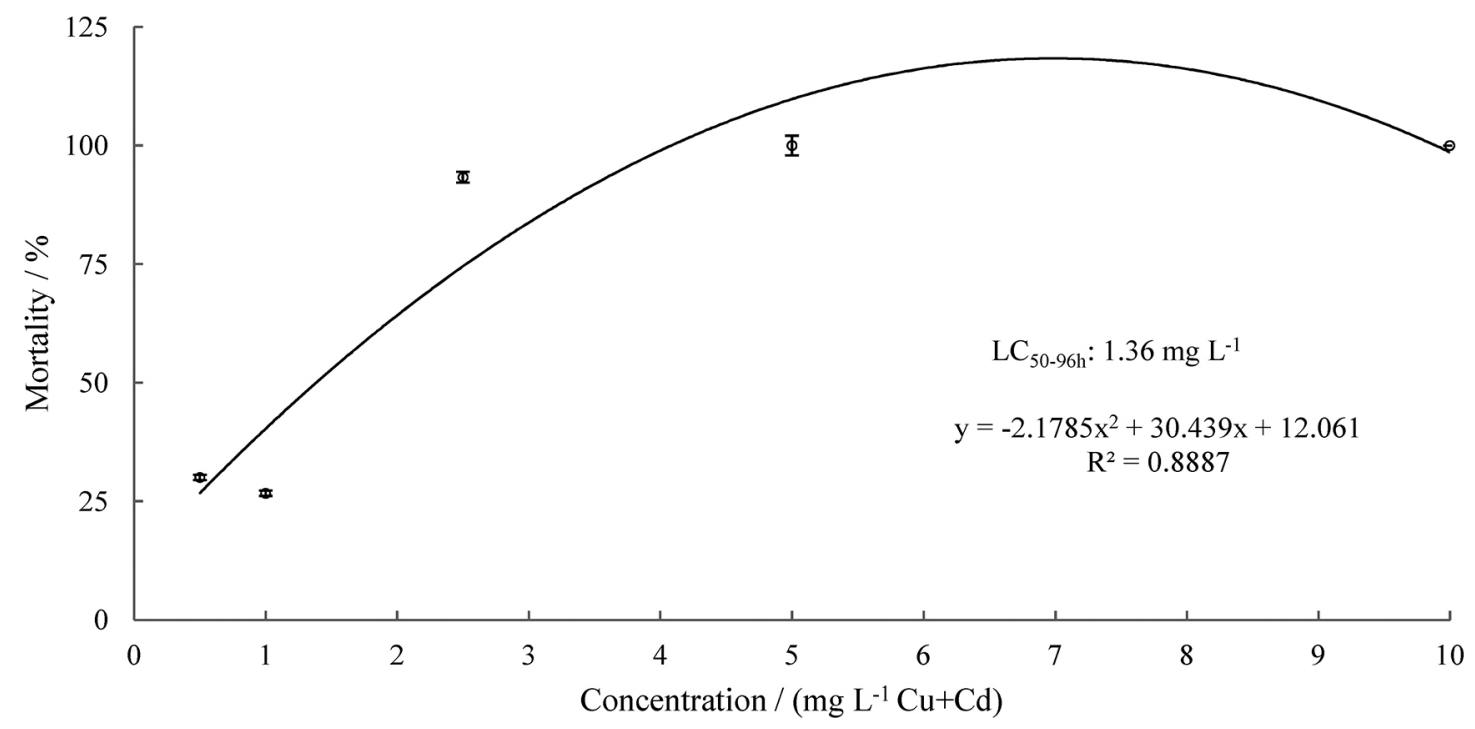

Figure 3. Mortality (\%) of Oreochromis niloticus, as a function of metal concentration in the $96 \mathrm{~h}$ acute toxicity test with $\mathrm{CuCl}_{2}+\mathrm{CdCl}_{2} \cdot \mathrm{H}_{2} \mathrm{O}$.

for the entire $96 \mathrm{~h}$ period. In addition, the $\%$ of mortality standard deviations were low in the concentration ranges for all three treatments.

Figure 3 presents evidence of the effect resulting from the combination of $\mathrm{CuCl}_{2}+\mathrm{CdCl}_{2} \cdot \mathrm{H}_{2} \mathrm{O}$ solutions, which leads to higher mortality percentages in comparison with exposure to either metal in isolation. This assessment is confirmed by the lethal concentrations $\left(\mathrm{LC}_{50-96 \mathrm{~h}}\right)$ for the tests of acute toxicity of these metals in different combinations. Lethal concentration $\left(\mathrm{LC}_{50}\right)$ values $(95 \%$ confidence intervals) were $3.53 \mathrm{mg} \mathrm{L}^{-1}$, with upper (UL) and lower (LL) limits of 4.42 to $2.82 \mathrm{mg} \mathrm{L}^{-1}$ for copper chloride, $20.1 \mathrm{mg} \mathrm{L}^{-1}$ with UL and LL of 23.3 to $17.4 \mathrm{mg} \mathrm{L}^{-1}$ for cadmium chloride and $1.36 \mathrm{mg} \mathrm{L}^{-1}$ with UL and LL of 1.59 to $1.16 \mathrm{mg} \mathrm{L}^{-1}$ for copper chloride + cadmium chloride.

Evaluating the response of $O$. niloticus to $\mathrm{CuSO}_{4}$ and $\mathrm{K}_{2} \mathrm{Cr}_{2} \mathrm{O}_{7}$ in tests with single metals, Masutti et al..$^{31}$ found that this species has a higher sensitivity to copper than to potassium chromate, with $\mathrm{LC}_{50-96 \mathrm{~h}}$ ranging from 0.32 to $0.65 \mathrm{mg} \mathrm{L}^{-1}$. Seddek ${ }^{32}$ determined the toxicity of copper as $\mathrm{CuSO}_{4}$ for this species, finding values for $\mathrm{LC}_{50-96 \mathrm{~h}}$ of $7.98 \mathrm{mg} \mathrm{L}^{-1} \mathrm{Cu}$, significantly higher than the results of Masutti et al. ${ }^{31}$ These differences can be linked to the chemical form of the metal since different salts were used and water chemistry. Cu toxicity is enhanced in low alkalinity waters and at low $\mathrm{pH} .{ }^{33,34}$ 
Oransaye and Ogunbor ${ }^{35}$ determined $\mathrm{LC}_{50-96 \mathrm{~h}}$ values of $1.0,0.68$ and $0.60 \mathrm{mg} \mathrm{L}^{-1} \mathrm{Cu}^{2+}$ for fingerlings of $O$. niloticus after 4,9 and 10 days, respectively, showing the response of toxicity with exposure time.

Results obtained in this study for $\mathrm{CdCl}_{2} \cdot \mathrm{H}_{2} \mathrm{O}$ in O. niloticus are close to those found by Annune et al., ${ }^{36}$ in which the $\mathrm{LC}_{50-96 \mathrm{~h}}$ were $19.3 \mathrm{mg} \mathrm{L}^{-1} \mathrm{Cd}$, whereas Garcia-Santos et al. ${ }^{37}$ found a $\mathrm{LC}_{50-96 \mathrm{~h}}$ of $14.8 \mathrm{mg} \mathrm{L}^{-1} \mathrm{Cd}$ for the same species. At a first glance, it could be concluded that $O$. niloticus is quite resistant to $\mathrm{Cd}$, and therefore not a suitable bioindicator for assessing the presence and the availability of metal in the environment. Before confirming this statement, it should be important to mention that among water properties, hardness and alkalinity are important parameters in the potential toxicity of $\mathrm{Cd}$. In the experimental conditions, fish acclimation was carried out with the same water as the control treatment, which constitutes a protection to fish when transferred to water in the presence of $\mathrm{Cd}$. The $96 \mathrm{~h}$ period is not enough to disturb the protection mechanism of $\mathrm{Ca}$ against $\mathrm{Cd}$ uptake from the water by the gill and can explain the fish tolerance. ${ }^{33}$ Certainly the $\mathrm{LC}_{50}$ for $\mathrm{Cd}$ would be lower for low alkalinity waters $\left(12.0 \mathrm{mg} \mathrm{L}^{-1}\right)$. On the other hand, the resistance of this species could be exploited in the investigation of the fate and interaction processes of this metal in aquatic organisms. ${ }^{37}$

It should be stressed that the above mentioned authors did not mention differences between nominal and measured dissolved metal concentrations (actual). Also, considerations of metal fate in relation to $\mathrm{pH}$ were not discussed in details. These assertions are justified, since differences can be expected in these concentrations, due to solubility products of metals, co-precipitation, adsorption on walls, among others.

As demonstrated in Figures 4 and 6, which represent the temporal variations of $\mathrm{Cu}^{2+}$ and $\mathrm{Cu}^{2+}+\mathrm{Cd}^{2+}$, a sharp decline of $\mathrm{Cu}^{2+}$ at the concentration $10.0 \mathrm{mg} \mathrm{L}^{-1} \mathrm{Cu}$ was observed. The reduction was caused by precipitation, due to the low solubility of copper hydroxide $\left(\mathrm{Kps} \mathrm{Cu}(\mathrm{OH})_{2}=1.60 \times 10^{-19}\right)$ and $\mathrm{pH}$ values during the test, 6.74 to 7.74 . According to Çoğun and Kargin, ${ }^{13}$ high values of $\mathrm{pH}$ contribute to diminish the copper solubility.

Precipitation was not observed during the test with $\mathrm{CdCl}_{2} \cdot \mathrm{H}_{2} \mathrm{O}$, which proved to be stable during the experimental period (Figure 5). The solubility product of cadmium hydroxide $\left(\mathrm{Kps} \mathrm{Cd}(\mathrm{OH})_{2}=5.30 \times 10^{-15}\right)$ is four orders of magnitude higher than that of cupric hydroxide, keeps metal stabilized in solution, even in higher concentrations and $\mathrm{pH}$ values used in the tests. Reductions in $\mathrm{Cd}$ concentration for metals in combination were due to the co-precipitation induced by $\mathrm{Cu}$ (Figure 6).

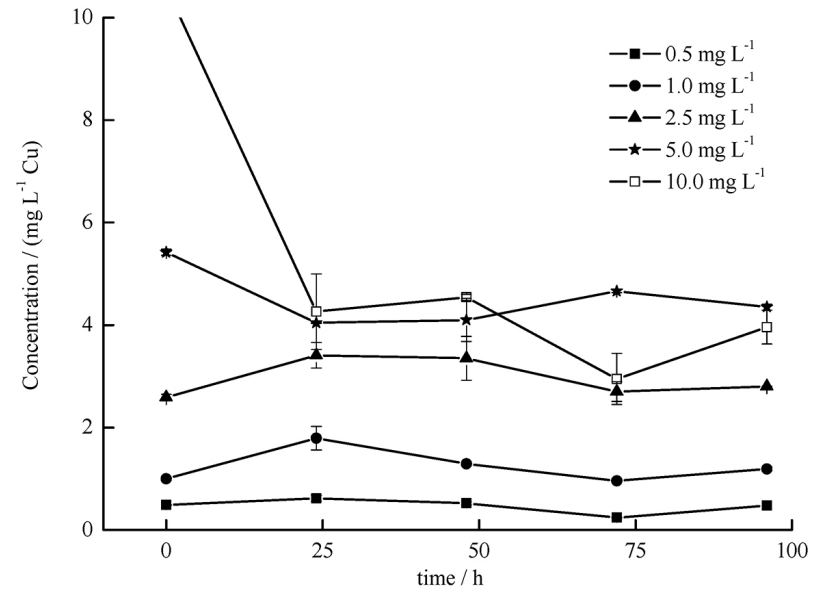

Figure 4. Temporal variation of copper concentrations obtained at every $24 \mathrm{~h}$ for the acute toxicity test in a $96 \mathrm{~h}$ period. Data refer to the metal actual concentrations of $0.5,1.0,2.5,5.0$ and $10.0 \mathrm{mg} \mathrm{L}^{-1} \mathrm{Cu}\left(\mathrm{CuCl}_{2}\right)$ solutions.

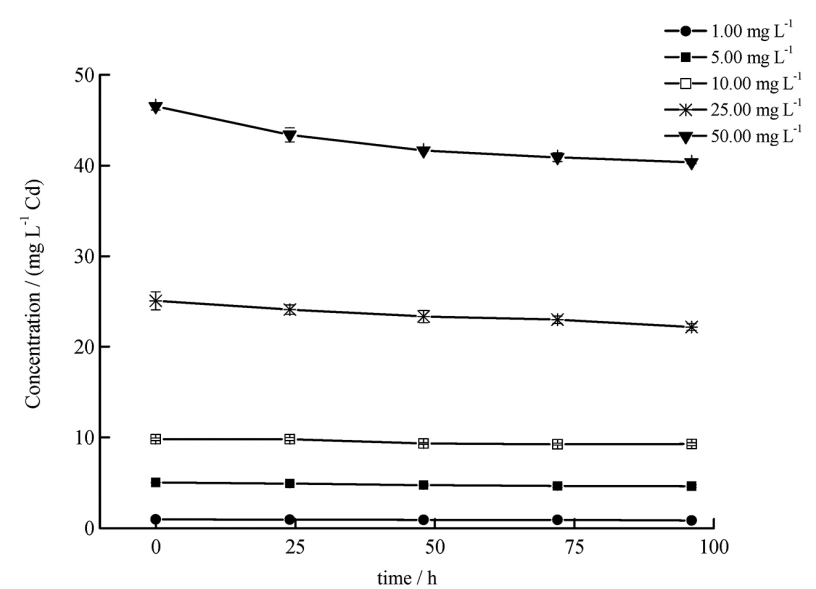

Figure 5. Temporal variations of cadmium concentration obtained every $24 \mathrm{~h}$ for the acute toxicity test in a $96 \mathrm{~h}$ period. Data refer to the metal actual concentrations of 1.0, 5.0, 10.0, 25.0 and $50.0 \mathrm{mg} \mathrm{L}^{-1} \mathrm{Cd}\left(\mathrm{CdCl}_{2}\right.$. $\mathrm{H}_{2} \mathrm{O}$ ) solutions.

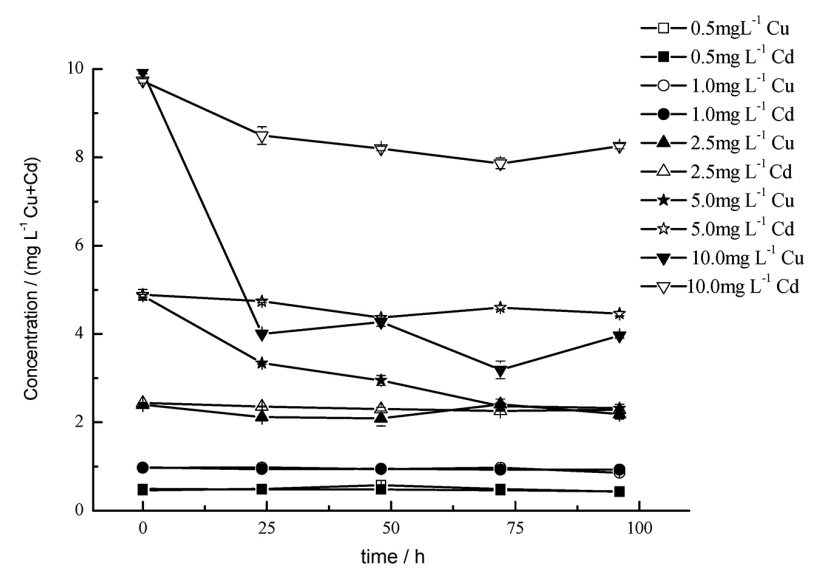

Figure 6. Temporal variations of copper and cadmium concentrations obtained every $24 \mathrm{~h}$ for the acute toxicity test in a $96 \mathrm{~h}$ period. Data refer to the metal actual concentrations of $0.5,1.0,2.5,5.0$ and $10.0 \mathrm{mg} \mathrm{L}^{-1}$ $(\mathrm{Cu}+\mathrm{Cd})$, as $\mathrm{CuCl}_{2}$ and $\mathrm{CdCl}_{2} \cdot \mathrm{H}_{2} \mathrm{O}$ salts in mixed solutions. In all situations, the ratio $1: 1$ for $\mathrm{Cu}: \mathrm{Cd}$ ratio is maintained as $1: 1(\mathrm{~m} / \mathrm{m})$ (for details see the text). 
Figures 4 to 6 denote the fate of $\mathrm{Cu}$ and $\mathrm{Cd}$ in the systems. $\mathrm{Cu}$ presented similar behavior at almost all concentrations, either alone or in combination. An exception was noted at $5.0 \mathrm{mg} \mathrm{L}^{-1} \mathrm{Cu}$, where the precipitation was slightly higher when the metals were mixed. Cadmium, which was approximately stable up to concentrations as high as 25.0 and $50.0 \mathrm{mg} \mathrm{L}^{-1}$, presented distinct behavior at $10.0 \mathrm{mg} \mathrm{L}^{-1}$ for both situations. Cadmium concentration decreased when in combination with $\mathrm{Cu}$, as explained earlier. Reductions observed for nominal concentrations of 25.0 and $50.0 \mathrm{mg} \mathrm{L}^{-1} \mathrm{Cd}$, are due to either adsorption to walls, or absorption of metal by fish.

Differences in actual and nominal concentrations were significative for $10.0 \mathrm{mg} \mathrm{L}^{-1} \mathrm{Cu}$, for both isolated and in combination with $\mathrm{Cd}$ (Figures 4 and 6). Highest percentage of mortality occurs at $10.0 \mathrm{mg} \mathrm{L}^{-1} \mathrm{Cu}$ (Figures 1 and 4) and nearly $60 \%$ of deaths were achieved for $5.0 \mathrm{mg} \mathrm{L}^{-1}$ $\mathrm{Cu}$ (Figure 1). Although the nominal concentration was reduced to the half during the first $24 \mathrm{~h}$ period (Figure 4), the $100 \%$ mortality observed in this treatment demonstrated that fish intake of $\mathrm{Cu}$ during the $24 \mathrm{~h}$ period is determining for fish response to the environmental stress, while nominal concentration was being reduced. A similar fate of $\mathrm{Cu}$ in solution was verified for the two metals in combination (Figure 3). In this case, due to the additional effect, 100\% mortality was verified at $5.0 \mathrm{mg} \mathrm{L}^{-1}$ for $\mathrm{Cu}$ and $\mathrm{Cd}$. In these situations, the kinetic of precipitation of $\mathrm{Cu}$ occurring in the first $24 \mathrm{~h}$ period persisted, still influencing fish toxicity.

Differences between expected and obtained concentrations show the importance of monitoring the chemical species of interest in a toxicity assay, considering that the actual concentrations of these chemicals must be used for obtaining the concentration factor, bioaccumulation and aquatic biomagnification data.

Due to all advantages in using this species for fish bioassays, ${ }^{20-22}$ these characteristics can, in fact, rank this species as a useful bioindicator in metal interactions to fish, allowing to assess for important mechanisms responses, like the Mts formation induced by metal stress. However, there has been an increasing appreciation of the need for studying sub-lethal effects and some growing interest in the physiological mechanisms by which various pollutants affect fish populations in the wild. In this sense, dosages for experimental work should be based on the $\mathrm{LC}_{50}$, which determines the optimum range for experiments, at levels that do not cause any acute toxicity.

Under the above described conditions, fish were affected with a formation of hypersecretion of mucus by the gills and skin at higher concentrations of $\mathrm{Cu}\left(5.0\right.$ and $\left.10.0 \mathrm{mg} \mathrm{L}^{-1}\right)$ and $\mathrm{Cd}\left(25.0\right.$ and $\left.50.0 \mathrm{mg} \mathrm{L}^{-1}\right)$ isolated and in combination (5.0 and $10.0 \mathrm{mg} \mathrm{L}^{-1}$ ). According to Heath, ${ }^{38}$ this is a protective mechanism against contamination, decreasing metal absorption through chelation and inhibition of diffusion. When excessive, this process can hamper the gas exchange, which explains why some fish appeared to be seeking oxygen at the air-water interface. This behavior is an additional component of the interference of metals with the respiratory mechanism and fish physiology. ${ }^{38,39}$

Another observed response was the presence of reddish spots in the body, especially in the contour of the lip in organisms exposed to copper isolated and in combination at concentrations of $10.0 \mathrm{mg} \mathrm{L}^{-1} \mathrm{Cu}$ and $10.0 \mathrm{mg} \mathrm{L}^{-1}(\mathrm{Cu}+\mathrm{Cd})$. This is due to the rapid loss of electrolytes from the body. ${ }^{40}$

\section{Chemical speciation - Wham 7.0 mathematical model}

The fate of $\mathrm{Cu}$ and $\mathrm{Cd}$ in the acute toxicity bioassay were assessed by the WHAM model, version 7.0. On Table 2, it is summarized the data obtained from the model output files.

Among the wide possibilities of evaluation, treatments involving 5.0 and $10.0 \mathrm{mg} \mathrm{L}^{-1} \mathrm{Cu}, 25.0$ and $50.0 \mathrm{mg} \mathrm{L}^{-1} \mathrm{Cd}$ and 5.0 and $10.0 \mathrm{mg} \mathrm{L}^{-1} \mathrm{Cu}+\mathrm{Cd}$ for the entire period of $96 \mathrm{~h}$ were selected. In addition, the model was also applied for metals $\mathrm{LC}_{50}$ concentrations (Table 2). The choices were based on metals equilibrium constants and on the Figures 4, 5 and 6 , which allow the calculation of metals actual concentrations. The solubilities of metals with time were stable for lower concentrations. A slight variations on metal concentrations were also a function of re-establishment of solutions up to the initial $40 \mathrm{~L}$ volume, required for static bioassays (Figures 4, 5 and 6).

For the input files, the model was feed with the molar salts composition and $\mathrm{NH}_{4}$, excreted by fish. The model was run twice, considering the minimum and maximum hardness values in the assays (Table 1 ). The dissolved organic carbon was fixed for all situations as $2.0 \times 10^{-3} \mathrm{~g} \mathrm{~L}^{-1}$ humic acid in colloidal phase. ${ }^{34}$

It was verified that $\mathrm{Cu}$ and $\mathrm{Cd}$ interact with hydroxide, carbonate and chloride forming inorganic complexes with very low activities. These complexes were in general less concentrated to $\mathrm{Cd}$ than to $\mathrm{Cu}$. Metal hydroxides varied from $10^{-10}$ to $10^{-7} \mathrm{~mol} \mathrm{~L} \mathrm{~L}^{-1}$ and $10^{-7}$ to $10^{-5} \mathrm{~mol} \mathrm{~L}^{-1}$ for $\mathrm{Cd}$ and $\mathrm{Cu}$, respectively. The same figures were followed for both metals in combination. For carbonates these activities were in the range of $10^{-10}$ to $10^{-6} \mathrm{~mol} \mathrm{~L}^{-1}$ to $\mathrm{Cd}$ and $10^{-8}$ to $10^{-5} \mathrm{~mol} \mathrm{~L}^{-1}$ to $\mathrm{Cu}$. When combined, the range of variation was narrower for $\mathrm{Cd}$, varying from $10^{-10}$ to $10^{-7} \mathrm{~mol} \mathrm{~L}^{-1}$ and maintained for $\mathrm{Cu}$. With chlorides, the range of molar activities varied from $10^{-9}$ to $10^{-5} \mathrm{~mol} \mathrm{~L}^{-1}$ to Cd isolated and $10^{-11}$ to $10^{-6} \mathrm{~mol} \mathrm{~L}^{-1}$ in metals combination conditions. $\mathrm{Cu}$ molar activity was $10^{-10}$ isolated and $10^{-9}$ in combination. 
Table 2. Carbonate alkalinity and important data of $\mathrm{Cu}$ and $\mathrm{Cd}$ speciation chemistry calculated by WHAM 7.0 model in the $96 \mathrm{~h}$ static bioassay test, considering the minimum and the maximum hardness concentrations observed in the aquariums and $\mathrm{LC}_{50}$ for $\mathrm{Cu}, \mathrm{Cd}$ and $\mathrm{Cu}+\mathrm{Cd}$

\begin{tabular}{|c|c|c|c|c|c|c|c|c|c|c|}
\hline \multirow{2}{*}{ Bioassay treatment } & \multicolumn{2}{|c|}{$\begin{array}{c}\text { Carbonate alkalinity / } \\
\left.(\mathrm{eq} \mathrm{L})^{-1}\right)\end{array}$} & \multicolumn{2}{|c|}{$\begin{array}{l}\text { Fraction bound to } \\
\text { colloidal / } \mathrm{HA}: \mathrm{Cu}\end{array}$} & \multicolumn{2}{|c|}{$\begin{array}{l}\text { Fraction bound to } \\
\text { colloidal / } \mathrm{HA}: \mathrm{Cd}\end{array}$} & \multicolumn{2}{|c|}{$\begin{array}{l}\text { Activity } \mathrm{Cu}^{2+} / \\
\left(\mathrm{mol} \mathrm{L}^{-1}\right) \\
\end{array}$} & \multicolumn{2}{|c|}{$\begin{array}{l}\text { Activity } \mathrm{Cd}^{2+} / \\
\left(\mathrm{mol} \mathrm{L}^{-1}\right)\end{array}$} \\
\hline & $\begin{array}{c}\text { Minimum } \\
\text { hardness }\end{array}$ & $\begin{array}{c}\text { Maximum } \\
\text { hardness }\end{array}$ & $\begin{array}{l}\text { Minimum } \\
\text { hardness }\end{array}$ & $\begin{array}{c}\text { Maximum } \\
\text { hardness }\end{array}$ & $\begin{array}{c}\text { Minimum } \\
\text { hardness }\end{array}$ & $\begin{array}{c}\text { Maximum } \\
\text { hardness }\end{array}$ & $\begin{array}{l}\text { Minimum } \\
\text { hardness }\end{array}$ & $\begin{array}{c}\text { Maximum } \\
\text { hardness }\end{array}$ & $\begin{array}{l}\text { Minimum } \\
\text { hardness }\end{array}$ & $\begin{array}{c}\text { Maximum } \\
\text { hardness }\end{array}$ \\
\hline \multicolumn{11}{|l|}{0 hour } \\
\hline $\mathrm{Cu} 5$ & $2.9410^{-4}$ & $3.7710^{-4}$ & 0.03803 & 0.03585 & - & - & $9.3510^{-6}$ & $7.6210^{-6}$ & - & - \\
\hline $\mathrm{Cu} 10$ & $2.0710^{-4}$ & $2.7510^{-4}$ & 0.02058 & 0.01952 & - & - & $2.8410^{-5}$ & $2.2710^{-5}$ & - & - \\
\hline $\mathrm{Cd} 25$ & $2.8710^{-4}$ & $3.5710^{-4}$ & - & - & 0.01341 & 0.01277 & - & - & $1.7710^{-4}$ & $1.7510^{-4}$ \\
\hline $\mathrm{Cd} 50$ & $2.7110^{-4}$ & $3.3710^{-4}$ & - & - & $8.0810^{-3}$ & $7.7910^{-3}$ & - & - & $3.1810^{-4}$ & $3.1610^{-4}$ \\
\hline $\mathrm{Cu} 5+\mathrm{Cd} 5$ & $2.7210^{-4}$ & $3.4810^{-4}$ & 0.03605 & 0.03392 & $8.5210^{-3}$ & $8.3410^{-3}$ & $1.0310^{-5}$ & $8.4110^{-6}$ & $3.6610^{-5}$ & $3.6110^{-5}$ \\
\hline $\mathrm{Cu} 10+\mathrm{Cd} 10$ & $2.1410^{-4}$ & $2.8310^{-4}$ & 0.02025 & 0.01916 & $5.2310^{-3}$ & $5.2110^{-3}$ & $2.6210^{-5}$ & $2.1010^{-5}$ & $7.2510^{-5}$ & $7.1710^{-5}$ \\
\hline \multicolumn{11}{|l|}{24 hours } \\
\hline $\mathrm{Cu} 5$ & $3.4510^{-4}$ & $4.3810^{-4}$ & 0.04903 & 0.04609 & - & - & $4.4310^{-6}$ & $3.6610^{-6}$ & - & - \\
\hline $\mathrm{Cu} 10$ & $3.4510^{-4}$ & $4.3810^{-4}$ & 0.04644 & 0.0437 & - & - & $4.4910^{-6}$ & $3.7110^{-6}$ & - & - \\
\hline $\mathrm{Cd} 25$ & $3.2710^{-4}$ & $4.0710^{-4}$ & - & - & 0.01435 & 0.01367 & - & - & $1.7010^{-4}$ & $1.6810^{-4}$ \\
\hline $\mathrm{Cd} 50$ & $3.5110^{-4}$ & $4.3710^{-4}$ & - & - & $9.2610^{-3}$ & $8.9410^{-3}$ & - & - & $2.9410^{-4}$ & $2.9110^{-4}$ \\
\hline $\mathrm{Cu} 5+\mathrm{Cd} 5$ & $3.4310^{-4}$ & $4.3410^{-4}$ & 0.05042 & 0.04720 & 0.01227 & 0.01196 & $4.4610^{-6}$ & $3.6810^{-6}$ & $3.5910^{-5}$ & $3.5310^{-5}$ \\
\hline $\mathrm{Cu} 10+\mathrm{Cd} 10$ & $3.2310^{-4}$ & $4.1110^{-4}$ & 0.04235 & 0.03967 & $9.6610^{-3}$ & $9.4910^{-3}$ & $6.2510^{-6}$ & $5.1310^{-6}$ & $6.2610^{-5}$ & $6.1710^{-5}$ \\
\hline \multicolumn{11}{|l|}{48 hours } \\
\hline$\overline{\mathrm{Cu} 5}$ & $3.0810^{-4}$ & $3.9210^{-4}$ & 0.04531 & 0.04262 & - & - & $7.1510^{-6}$ & $5.8610^{-6}$ & - & - \\
\hline $\mathrm{Cu} 10$ & $3.0710^{-4}$ & $3.9010^{-4}$ & 0.04568 & 0.04293 & - & - & $7.1510^{-6}$ & $5.8610^{-6}$ & - & - \\
\hline $\mathrm{Cd} 25$ & $3.3510^{-4}$ & $4.1710^{-4}$ & - & - & 0.01498 & 0.01423 & - & - & $1.6510^{-4}$ & $1.6310^{-4}$ \\
\hline $\mathrm{Cd} 50$ & $3.4310^{-4}$ & $4.2710^{-4}$ & - & - & $9.3910^{-3}$ & $9.0510^{-3}$ & - & - & $2.8510^{-4}$ & $2.8210^{-4}$ \\
\hline $\mathrm{Cu} 5+\mathrm{Cd} 5$ & $3.4210^{-4}$ & $4.3210^{-4}$ & 0.05530 & 0.05167 & 0.01259 & 0.01228 & $4.1710^{-6}$ & $3.4410^{-6}$ & $3.3210^{-5}$ & $3.2710^{-5}$ \\
\hline $\mathrm{Cu} 10+\mathrm{Cd} 10$ & $2.4110^{-4}$ & $3.0610^{-4}$ & 0.01057 & $9.4710^{-3}$ & $5.1910^{-4}$ & $5.2610^{-4}$ & $9.7610^{-6}$ & $8.1510^{-6}$ & $4.5510^{-3}$ & $4.5410^{-3}$ \\
\hline \multicolumn{11}{|l|}{72 hours } \\
\hline$\overline{\mathrm{Cu} 5}$ & $3.1710^{-4}$ & $4.0510^{-4}$ & 0.04165 & 0.03927 & - & - & $7.3310^{-6}$ & $5.9910^{-6}$ & - & - \\
\hline $\mathrm{Cu} 10$ & $3.2710^{-4}$ & $4.1210^{-4}$ & 0.06692 & 0.06242 & - & - & $4.0210^{-6}$ & $3.3210^{-6}$ & - & - \\
\hline $\mathrm{Cd} 25$ & $3.5410^{-4}$ & $4.4110^{-4}$ & - & - & 0.01552 & 0.01477 & - & - & $1.5910^{-4}$ & $1.5710^{-4}$ \\
\hline $\mathrm{Cd} 50$ & $3.5410^{-4}$ & $4.4010^{-4}$ & - & - & $9.6310^{-3}$ & $9.2910^{-3}$ & - & - & $2.8010^{-4}$ & $2.7710^{-4}$ \\
\hline $\mathrm{Cu} 5+\mathrm{Cd} 5$ & $3.5410^{-4}$ & $4.4510^{-4}$ & 0.06285 & 0.05856 & 0.01399 & 0.01358 & $3.1710^{-06}$ & $2.6310^{-6}$ & $3.5110^{-5}$ & $3.4610^{-5}$ \\
\hline $\mathrm{Cu} 10+\mathrm{Cd} 10$ & $3.3910^{-4}$ & $4.2910^{-4}$ & 0.04994 & 0.04666 & 0.01106 & 0.01081 & $4.5410^{-06}$ & $3.7410^{-6}$ & $5.8510^{-5}$ & $5.7610^{-5}$ \\
\hline \multicolumn{11}{|l|}{96 hours } \\
\hline$\overline{\mathrm{Cu} 5}$ & $3.1010^{-4}$ & $3.9510^{-4}$ & 0.04208 & 0.03966 & - & - & $7.6610^{-6}$ & $6.2610^{-6}$ & - & - \\
\hline $\mathrm{Cu} 10$ & $3.1210^{-4}$ & $3.9710^{-4}$ & 0.04640 & 0.04363 & - & - & $6.7810^{-6}$ & $5.5610^{-6}$ & - & - \\
\hline $\mathrm{Cd} 25$ & $3.2110^{-4}$ & $3.9910^{-4}$ & - & - & 0.01510 & 0.01435 & - & - & $1.5710^{-4}$ & $1.5510^{-4}$ \\
\hline Cd50 & $3.1310^{-4}$ & $3.9010^{-4}$ & - & - & $9.3710^{-3}$ & $9.0210^{-3}$ & - & - & $2.7610^{-4}$ & $2.7310^{-4}$ \\
\hline $\mathrm{Cu} 5+\mathrm{Cd} 5$ & $3.4210^{-4}$ & $4.3010^{-4}$ & 0.06437 & 0.05994 & 0.01349 & 0.01310 & $3.5210^{-6}$ & $2.9110^{-6}$ & $3.2810^{-5}$ & $3.2310^{-5}$ \\
\hline $\mathrm{Cu} 10+\mathrm{Cd} 10$ & $3.1510^{-4}$ & $4.0010^{-4}$ & 0.04183 & 0.03918 & $9.3610^{-3}$ & $9.2010^{-3}$ & $6.7610^{-6}$ & $5.5410^{-6}$ & $6.1810^{-5}$ & $6.0910^{-5}$ \\
\hline $\mathrm{LC}_{50} \mathrm{Cu}$ & $3.2110^{-4}$ & $4.0710^{-4}$ & 0.0516 & 0.04844 & - & - & $5.6810^{-6}$ & $4.6710^{-6}$ & - & - \\
\hline $\mathrm{LC}_{50} \mathrm{Cd}$ & $3.1410^{-4}$ & $3.9110^{-4}$ & - & - & 0.01600 & 0.01518 & - & - & $1.4310^{-4}$ & $1.4210^{-4}$ \\
\hline $\mathrm{LC}_{50} \mathrm{Cu}+\mathrm{LC}_{50} \mathrm{Cd}$ & $3.4510^{-4}$ & $4.3210^{-4}$ & 0.10422 & 0.09626 & 0.01907 & 0.01819 & $1.9410^{-6}$ & $1.6210^{-6}$ & $1.0110^{-5}$ & $9.9610^{-6}$ \\
\hline
\end{tabular}

H.A $=$ humic acid.

According to the model calculation only one chloride complex was observed with $\mathrm{Cu}\left(\mathrm{CuCl}^{+}\right)$and two of them were formed with $\mathrm{Cd}\left(\mathrm{CdCl}^{+} ; \mathrm{CdCl}_{2}\right)$.

During the whole experiment, alkalinity varied in the range of 2.07 to $3.4510^{-4} \mathrm{eq} \mathrm{L}^{-1}$ for the low hardness water and from 2.75 to $4.4510^{-4} \mathrm{eq} \mathrm{L}^{-1}$ to the higher hardness water. Without any exception, an increase in hardness led to an increase in alkalinity. The free ion activity of both metals diminished when both of these variables were increased in the observed experimental $\mathrm{pH}$ variation. Metals inorganic complexes compete with DOC (dissolved organic carbon), as an increase in these variables reduced the metal fraction bounded to the colloidal humic acid. The fraction of $\mathrm{Cu}$ bounded to the 
colloidal humic acid was higher in comparison to $\mathrm{Cd}$ (Table 2). The bioavailability and toxicity of $\mathrm{Cd}$ was less affected by DOC than the other metals. ${ }^{41}$

This can confirm that toxicity decreases as hardness and alkalinity increase. This could be expected for both metals, although hardness had a minor effect on $\mathrm{Cu}$ solubility, but can protect fish in low alkalinity waters by $\mathrm{Ca}$ competition with divalent metals. ${ }^{33}$ By considering the water properties and metals interactions with the water components, WHAM model revealed that the availability of the free $\mathrm{Cu}^{2+}$ was reduced in $18 \%$ in the hardness interval of this experiment, whereas for $\mathrm{Cd}^{2+}$ only a $2 \%$ reduction was verified, being $\mathrm{Cu}$ more affected than $\mathrm{Cd} .{ }^{42}$ For both metals, the free ions concentration reductions were stable from 0 to $96 \mathrm{~h}$ (Table 2), indicating good experimental conditions. The intensity of interactions of both metals differs, resulting that the $\mathrm{Cd}$ free ion is one order of magnitude higher than that of $\mathrm{Cu}$ free ion. It can also be observed that the fraction bounded to the humic acid was reduced as metals concentrations increased. This is probably to the saturation of active sites in the colloidal phase. ${ }^{43}$

If one take into account the above described interactions for the metals at $\mathrm{LC}_{50}$ concentrations it can be seen that the free $\mathrm{Cu}$ ion $\left(\mathrm{Cu}^{2+}\right)$ was $10.2 \%$ for low hardness water and $8.4 \%$ for the higher hardness. Cadmium availability of the free ion $\left(\mathrm{Cd}^{2+}\right)$ varied only from 82 to $81.6 \%$ under the same water conditions. When combined, the free ion availability would be in the range of 9.2 to $7.7 \%$ for $\mathrm{Cu}$ and 84.1 to $83 \%$ for $\mathrm{Cd}$. In other words, in the hardness range in which these assays were carried out, the metal fractions available on $\mathrm{LC}_{50}$ concentrations were only 0.35 to $0.28 \mathrm{mg} \mathrm{L}^{-1} \mathrm{Cu}\left(\mathrm{LC}_{50}=3.53 \mathrm{mg} \mathrm{L}^{-1} \mathrm{Cu}\right) ; 16.48$ to $16.40 \mathrm{mg} \mathrm{L}^{-1} \mathrm{Cd}\left(\mathrm{LC}_{50}=20.10 \mathrm{mg} \mathrm{L}^{-1} \mathrm{Cd}\right)$. For the two metals combined, 0.12 to $0.10 \mathrm{mg} \mathrm{L}^{-1} \mathrm{Cu}$ and 1.14 to $1.13 \mathrm{mg} \mathrm{L}^{-1} \mathrm{Cd}\left(\mathrm{LC}_{50}=1.36 \mathrm{mg} \mathrm{L}^{-1} \mathrm{Cu}+\mathrm{Cd}\right)$. These values are more realistic for $\mathrm{Cu}$, but still not for $\mathrm{Cd}$ isolated. Although it is stated that $\mathrm{Cd}$ toxicity diminished as hardness increased, $\mathrm{pH}$ influence is biphasic increasing toxicity below $\mathrm{pH} 7.0$ and diminished again if it goes further down (pH 5.50), the water chemistry do not alter the speciation of $\mathrm{Cd}$ as it does for $\mathrm{Cu}^{42}$ It should be denoted that under the assay conditions, in combination the toxicity of $\mathrm{Cd}$ to tilapia was well reduced.

Although this particular species appears to be highly tolerant to $\mathrm{Cu}$ and $\mathrm{Cd}$, with $\mathrm{LC}_{50}$ values out of the environment realism, the fate of metals in the medium is a characteristic of the specific site, which can impair and conditioning the free ion activity, which is the one available to the biota. Inasmuch metals do not occur alone in a natural environment, an additive effect like the one mentioned in this paper should be considered.

\section{Conclusions}

The static bioassay system was stable during the entire period of the experiment, observed by the physico-chemical variables data measured at every $24 \mathrm{~h}$. In this sense, fish response was only due to the effects of the studied chemicals.

The fate of metals depends not only on their inherent characteristics, but also on the abiotic medium composition. The low solubility product of $\mathrm{Cu}$ hydroxide in the $\mathrm{pH}$ experimental range acts upon $\mathrm{Cd}$ at $10 \mathrm{mg} \mathrm{L}^{-1}(\mathrm{Cu}+\mathrm{Cd})$ through a co-precipitation when combined.

When considering both actual metal concentrations and bioavailable metal fractions to the biota, assessed by the mathematical speciation model, the $\mathrm{LC}_{50}$ can reach environmental realistic concentrations. This could not be stated in the Cd isolated assay, but only when this metal is in combination with $\mathrm{Cu}$.

The acute toxicity of $\mathrm{Cd}$ and $\mathrm{Cu}$ to tilapia differs significantly, being higher for $\mathrm{Cu}$, an essential element, than for $\mathrm{Cd}$, which has no recognized biological function. In combination $(\mathrm{Cu}+\mathrm{Cd})$, the $\mathrm{LC}_{50}$ is decreased nearly two fold compared to that observed for $\mathrm{Cu}$.

To state if tilapia is a good or not so good bio-indicator of $\mathrm{Cd}$ and $\mathrm{Cu}$ toxicity there is a need to consider not only the nominal metal concentrations, but also the characteristics of the abiotic medium which implies metals bioavailability.

\section{Supplementary Information}

Supplementary Information (water chemistry interactions conditioning metals availability) is available free of charge in PDF file at http://jbcs.sbq.org.br.

\section{Acknowledgments}

The authors express their gratitude to Fundação de Amparo à Pesquisa do Estado de São Paulo (FAPESP), SP, Brazil, for providing financial support to this research (Process No. 2010/19588-0) and the MSc scholarship to M. A. S. (Process No. 2010/14021-1).

\section{References}

1. Gupta, A. K.; Rajbanshi, V. K.; Acta Hydrochim. Hydrobiol. 1991, 19, 331.

2. Hartwell, S. I.; Alden, R. W.; Wright, D. A.; Ailstock, S.; Kerhin, R.; Environ. Toxicol. Chem 2000, 19, 1753.

3. Nogami, E. M.; Kimura, C. C. M.; Rodrigues, C.; Malagutti, A. R.; Lenzic, E.; Nozaki, J.; Ecotoxicol. Environ. Saf. 2000, $45,291$. 
4. Almeida, J. A.; Novelli, E. L. B.; Silva, M. D. P.; Junior, R. A.; Environ. Pollut. 2001, 114, 169.

5. Mansour, S. A.; Sidky, M. M.; Food Chem. 2003, 82, 181.

6. Arkhipchuk, V. V.; Garanko, N. N.; Ecotoxicol. Environ. Saf. 2005, 62, 42.

7. Eroglu, K.; Atli, G.; Canli, M.; Bull. Environ. Contam. Toxicol. 2005, 75, 390.

8. Murano, H.; Matsuzaki, K.; Shiraishi, H.; Wakabayashi, M.; Fish Sci. 2007, 73, 1078.

9. Atli, G.; Canli, M.; Environ. Toxicol. Pharmacol. 2008, 25, 33.

10. Costa, P. M.; Diniz, M. S.; Caeiro, S.; Lobo, J.; Martins, M.; Ferreira, A. M.; Caetano, M.; Valec, C.; DelValls, A.; Costa, M. H.; Aquat. Toxicol. 2009, 92, 202.

11. Atli, G.; Canli, M.; Ecotoxicol. Environ. Saf. 2010, 73, 1884.

12. Biney, C.; Amuzu, A. T.; Calamari, D.; Kaba, N.; Mbome, I. L.; Naeve, H.; Ochumba, P. B. O.; Osibanjo, O.; Radegonde, V.; Saad, M. A. H.; Ecotoxicol. Environ. Saf. 1994, 28, 134.

13. Çoğun, H. Y.; Kargin, F.; Chemosphere 2004, 55, 277.

14. Cicik, B.; Ay, O.; Karayakar, F.; Bull. Environ. Contam. Toxicol. 2004, 72, 141 .

15. Benaduce, A. P. S.; Kochhann, D.; Flores, E. M. M.; Dressler, V. L.; Baldisserotto, B.; Arch. Environ. Contam. Toxicol. 2008, 54, 274.

16. Hollis, L.; McGeer, J. C.; McDonald, D. G.; Wood, C. M.; Aquat. Toxicol. 1999, 46, 101.

17. Li, J.; Quabius, E. S.; Wendelaar Bonga, S. E.; Flik, G.; Lock, R. A. C.; Aquat. Toxicol. 1998, 43, 1.

18. Chen, Q. L.; Luo, Z.; Zheng, J. L.; Li, X. D.; Liu, C. X.; Zhao, Y. H.; Gong, Y.; Ecotoxicol. Environ. Saf. 2012, 76, 126.

19. Pelgrom, S. M. G. J.; Lamers, L. P. M.; Lock, R. A. C.; Balm, P. H. M.; Bonga, S. E. W.; Environ. Pollut. 1995, 90, 415.

20. Almeida, J. A.; Diniz, Y. S.; Marques, S. F.; Faine, L. A.; Ribas, B. O.; Burneiko, R. C.; Novelli, E. L.; Environ. Int. 2002, 27, 673.

21. Girón-Pérez, M. I.; Santerre, A.; Gonzalez-Jaime, F.; CasasSolis, J.; Hernandez-Coronado, M.; Peregrina-Sandoval, J.; Takemura, A.; Zaitseva, G.; Fish Shellfish Immunol. 2007, 23, 760.

22. Wu, S. M.; Lin, H. C.; Yang, W. L.; Aquat. Toxicol. 2008, 87, 296.

23. EPA; Methods for Measuring the Acute Toxicity of Effluents and Receiving Waters to Freshwater and Marine Organisms, $5^{\text {th }}$ ed.; Environmental Protection Agency: Washington, DC, USA, 2002.

24. Associação Brasileira de Normas Técnicas; NBR 15088: Ecotoxicologia Aquática - Toxicidade Aguda - Método de Ensaio com Peixes; ABNT: São Paulo, Brasil, 2011.
25. APHA; Standard Methods for the Examination of Water and Wastewater, $17^{\text {th }}$ ed.; American Public Health Association: Washington, DC, USA, 1989.

26. Reis, B. F.; Vieira, J. A.; Krug, F. J.; Gine, M. F.; J. Braz. Chem. Soc. 1997, 8, 523.

27. Tipping, E.; Lofts, S.; Aquat. Toxicol. 2013, 142-143, 114.

28. Hamilton, M. A.; Russo, R. C.; Thurston, R. V.; Environ. Sci. Technol. 1977, 11, 714.

29. Benli, A. C. K.; Koksal, G.; Turk. J. Vet. Anim. Sci. 2005, 29 , 339.

30. EPA/600/4-91/003; Short-Term Methods for Estimating the Chronic Toxicity of Effluents and Receiving Waters to Marine and Estuary Organisms, $2^{\text {nd }}$ ed.; Klemm, D. J.; Morrison, G. E.; Norber-King, T. J.; Peltier, W. H.; Heber, M. A., eds.; EPA: Washington, USA, 1994.

31. Masutti, M. B.; Espíndola, E. L. G.; Nogueira, A. M.; Simões, F. C. F.; J. Braz. Soc. Ecotoxicol. 2006, 1, 37.

32. Seddek, A.; Assiut Vet. Med. J. 1990, 23, 166.

33. Dorothy, R.; Roseboom, D. P.; Acute Toxicity of Copper to Some Fishes in High Alkalinity Water; Illinois State Water Survey: Champaign, IL, USA, 1978. Available at http://webh2o.sws. uiuc.edu/pubdoc/C/ISWSC-131.pdf, accessed in May 2016.

34. Macdonald, S.; Bishop, A. G.; Prenzler, P. D.; Robards, K.; Anal. Chim. Acta 2004, 527, 105.

35. Oronsaye, J. A. O.; Ogunbor, E. O.; Indian J. Anim. Sci. 1998, 68, 1001.

36. Annune, P. A.; Ebele, S. O.; Oladimeji, A. A.; J. Environ. Sci. Health, Part A: Toxic/Hazard. Subst. Environ. Eng. 1994, 29, 1357.

37. Garcia-Santos, S.; Fontainhas-Fernandes, A.; Wilson, J. M.; Environ. Toxicol. 2006, 21, 36.

38. Heath, A. G.; Water Pollution and Fish Physiology, $2^{\text {nd }}$ ed.; CRC Press: Boca Raton, USA, 1995.

39. Lichtenfels, A. J. F. C.; Lorenzi, G.; Guimaraes, E. T.; Macchione, M.; Saldiva, P. H. N.; J. Comp. Pathol. 1996, 115, 47.

40. Handy, R. D.; Eddy, F. B.; Baines, H.; Biochim. Biophys. Acta 2002, 1566, 104.

41. Spry, D. J.; Wiener, J. G.; Environ. Pollut. 1991, 71, 243.

42. Wren, C. D.; Stephenson, G. L.; Environ. Pollut. 1991, 71, 205.

43. Buffle, J.; De Vitre, R.; Chemical and Biological Regulation of Aquatic Systems; Lewis Publishers: London, 1995.

Submitted: February 25, 2016

Published online: May 19, 2016

FAPESP has sponsored the publication of this article. 